\title{
Overexpression of $\alpha$-enolase correlates with poor survival in canine mammary carcinoma
}

Pei-Yi Chu ${ }^{1,2}$, Nicholas C Hsu ${ }^{3}$, Albert T Liao ${ }^{2}$, Neng-Yao Shih ${ }^{4^{*}}$, Ming-Feng Hou ${ }^{5^{*}}$ and Chen-Hsuan Liu ${ }^{2^{*}}$

\begin{abstract}
Background: $\alpha$-Enolase (ENO1) is a key glycolytic enzyme implicated in the development of many human cancers including breast cancer. Increased expression of ENO1 has recently been reported in estrogen (ER)-positive human breast cancer patients. The present study examined the expression of ENO1 and assessed its significance in canine mammary carcinoma.

Results: Immunohistochemical staining was employed to investigate the expression of ENO1 in 82 cases of canine mammary tumor (32 benign tumors and 50 carcinomas). Quantification of immunohistochemistry was carried out using Quick score and the results showed cytoplasmic ENO1 overexpression in 9 of the 50 carcinomas (18\%). Overexpression of ENO1 correlated significantly with shorter cause-specific survival $(P=0.019)$, but was not associated with ER positivity in canine mammary carcinoma.
\end{abstract}

Conclusions: Our findings suggest that overexpression of ENO1 may be used as a prognostic marker for poor outcome in canine mammary carcinoma.

\section{Background}

Canine mammary tumor is one of the most common neoplasms in female dogs. Similar to human breast cancer, canine mammary tumor is spontaneous, and the predominant malignant histological type is carcinoma [1-3]. Previous studies have shown that estrogen and progesterone receptors (ER/PR), and epidermal growth factor receptor 2 (HER2) are expressed in canine mammary carcinoma with clinical implications similar to those in human [4-7]. It has been proposed that canine mammary carcinomas may be a suitable model for comparative oncology studies [4,5,7-9].

$\alpha$-Enolase (ENO1) is a glycolytic enzyme that converts 2-phosphoglycerate into phosphoenolpyruvate in glycolysis and a multifunctional protein that play a crucial role in a variety of biological and pathophysiological processes [10]. ENO1 may act as a stress protein that promotes hypoxic tolerance in tumor cells by increasing

\footnotetext{
* Correspondence: jshih@nhri.org.tw; mifeho@kmu.edu.tw; chhsuliu@ntu.edu. tw

${ }^{2}$ Department and Graduate Institute of Veterinary Medicine, School of Veterinary Medicine, National Taiwan University, No. 1, Section 4, Roosevelt Road, Taipei, 10617, Taiwan

${ }^{4}$ National Institute of Cancer Research, National Health Research Institutes, No.367, Shengli Road, Tainan, 70456, Taiwan

Full list of author information is available at the end of the article
}

anaerobic metabolism [11]. ENO1 may also function as a plasminogen receptor on the surface of a variety of hematopoetic, epithelial and endothelial cells [12-17]. Recently, many lines of evidence suggested that ENO1 might contribute to tumor malignancy [17-26]. Upregulation of ENO1 gene has been observed in several highly tumorigenic or metastatic cell lines $[21,23,24]$ and enzymatic activities in breast cancer concluded a role of ENO1 in tumor progression [20]. A bioinformatics study using gene chips and ESTs databases further supports a correlation between ENO1 expression and tumorigenicity [18]. Increased cell-surface expression of ENO1 promotes cell transformation and invasion in non-small cell lung cancer and cancer of head and neck $[19,22]$. The expression of ENO1 has been also reported in pancreatic carcinoma [26] and hepatitis $C$ virusrelated hepatocellular carcinoma [25]. More recently, higher ENO1 expression was detected in ER+ breast cancer patients compared to ER- patients [27]. Patients with high ENO1 expression also had a poor prognosis with greater tumor size, poor nodal status, and a shorter disease-free survival [27].

Given the epidemiological and pathological similarity between canine mammary carcinoma and human breast cancer, and that canine mammary carcinoma may be a 
good animal model for the understanding of carcinogenesis and the development of treatment, the present study examined the expression of ENO1 and assessed its clinical significance in canine mammary carcinoma.

\section{Results}

The mean age when tumors were first identified was $11.2 \pm 2.9$ years (range 4-18 years). The mean maximum tumor diameter was $3.8 \pm 2.9 \mathrm{~cm}$ (range $0.2-14 \mathrm{~cm}$ ). Of the 82 dogs, 20 had undergone ovariohysterectomy before presentation for surgical excision of the primary tumor(s). 32 cases (39\%) were benign tumors and 50 cases $(61 \%)$ were histologically confirmed as mammary carcinoma.

Immunohistochemical analyses revealed that mammary carcinomas have higher expression of ENO1 as compared to benign tumors (Figure 1 and Table 1). Overexpression of ENO1 (as defined by a Quick score of 12 or greater) was only identified in $18 \%$ (9/50) of dogs with mammary carcinoma and none in the benign tumors. Moreover, ENO1 overexpression occurred preferentially in the tumor cells and not the adjacent non-tumor cells in mammary carcinoma (Figure 2 and Table 2, $P=0.011$ ). The overexpression of ENO1 was not statistically associated with clinicopathologic features such as age, ovariohysterectomy, size and grade of tumor, histological classification, location of affected glands, and expression of ER, PR, and HER2. We employed the same Quick score system to quantify ER expression, although not statistically significant, a trend toward positive correlation between high expression of ER (score of $\geqq 12$ ) and ENO1 overexpression was found $(P=0.063$, Table 3$)$. Kaplan Meier survival analysis showed that cytoplasmic overexpression of ENO1 correlated significantly with shorter 5 -year cause-specific survival in canine mammary carcinoma $(P=0.019$, Figure 3$)$. Because age is strongly related to death, control of the effect of age was accomplished by adding the mean age as a covariate to the multivariate survival analysis. The results of the age-adjusted
Table 1 Immunohistochemical semiquantitation of ENO1 expression with the Quick score in canine mammary tumor

\begin{tabular}{lccccc}
\hline Histological classification & \multicolumn{5}{c}{ Quick score } \\
\cline { 2 - 6 } & $\mathbf{0 - 3}$ & $\mathbf{4 - 6}$ & $\mathbf{8 - 1 0}$ & $\mathbf{1 2 +}$ & total \\
\hline Benign tumor & 17 & 13 & 2 & 0 & 32 \\
Carcinoma & 15 & 15 & 11 & 9 & 50 \\
\hline
\end{tabular}

Cox regression model showed that ENO1 overexpression retained statistical significance on cause-specific survival $(P=0.044$, Table 4$)$.

\section{Discussion}

Breast cancer comparative oncology that integrates the study of canine mammary carcinoma into studies of human breast carcinoma may be uniquely positioned to take advantage of the epidemiological and clinicopathologic similarities between the two cancers of different species to improve our understanding of breast cancer biology and therapy.

Enhanced expression of ENO1 has been implicated in human tumorigenesis and also used as a diagnostic marker for human lung cancer [19,23,28-31]. ENO1 overexpression was also preferentially identified in human ER-positive breast cancer [27]. In this study, we investigated the expression and clinical relevance of ENO1 in canine mammary carcinoma. Immunohistochemical analysis revealed that overexpression of ENO1 was only detected in tumor cells of canine mammary carcinoma and significantly correlated with shorter 5 -year cause-specific survival. The results of the age-adjusted Cox regression analysis further indicated that ENO1 overexpression was significantly and independently associated with shorter cause-specific survival. Unlike results from human breast cancer study, our findings suggested that ER positivity was not associated with ENO1 overexpression in canine mammary carcinoma. Although quantification of ER expression with the same Quick score system used for ENO1 revealed a trend

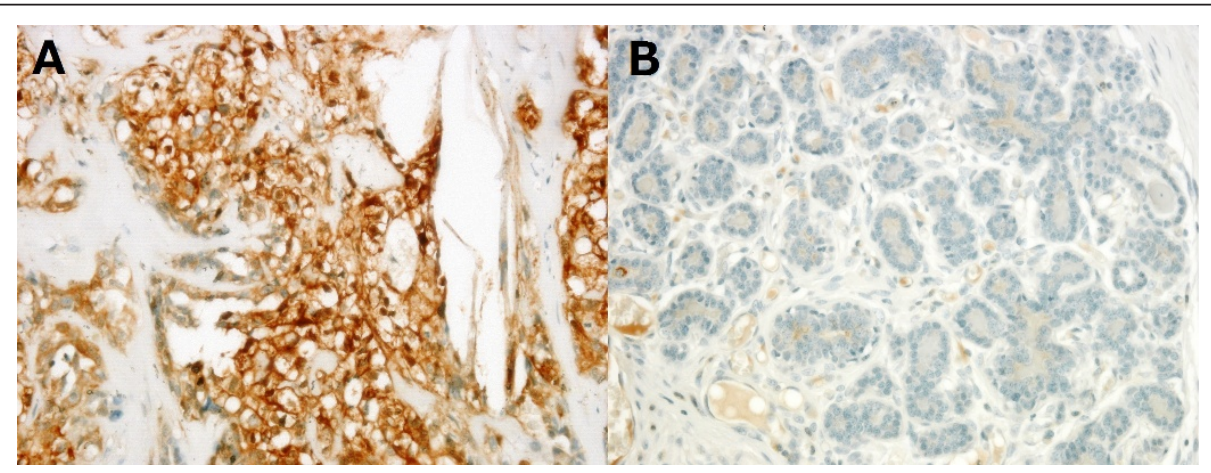

Figure 1 Representative figures of the immunohistochamical staining of ENO1 in (A) canine mammary carcinoma (Quick score = 12) and $(B)$ benign tumor (Quick score $=0$ ). Carcinoma cells showed strong cytoplasmic staining of ENO1 (400X). 


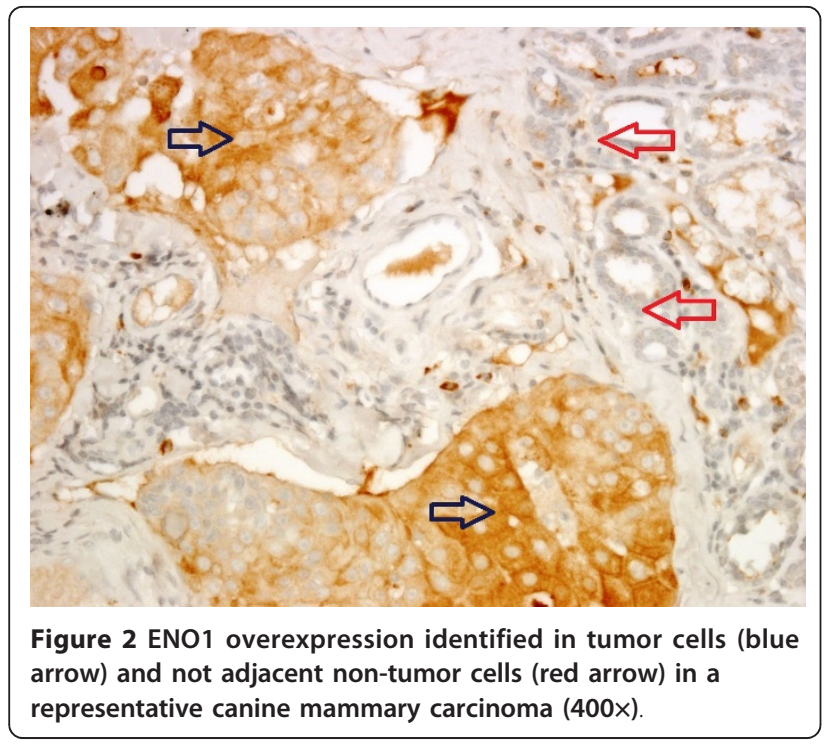

toward positive correlation between overexpression of ER and ENO1 $(P=0.063)$. Further investigation is required to elucidate whether the molecular events that underlie ENO1 overexpression in canine mammary carcinoma is ER signaling machinery-associated or -dependent as proposed in human breast cancer [27].

The limitations of this study are primarily related to the limited number of cases and its design as a retrospective study which may make collecting complete clinical information difficult. The finding of ENO1 overexpression in the neoplastic tissue of canine mammary carcinoma and its possible role in the prognosis of this disease is clinically relevant, as ENO1 expression could be widely determined on routinely processed, paraffin-embedded tissues. Moreover, agents with ENO1 attenuation activity might provide an effective strategy for the treatment of breast cancer for both dogs and human and merit further investigation.

\section{Conclusions}

Overexpression of ENO1 occurs in the neoplastic tissue of a subset of dogs with canine mammary carcinoma.

Table 2 Overexpression of ENO1 in canine mammary tumor

\begin{tabular}{|c|c|c|c|c|c|}
\hline ENO1 expression & & $\begin{array}{l}\text { Benign } \\
\text { tumor }\end{array}$ & Carcinoma & Total & $P$ \\
\hline \multicolumn{6}{|l|}{ Tumor part } \\
\hline $\begin{array}{l}\text { Quick } \\
\text { score }\end{array}$ & $<12$ & $32(43.8 \%)$ & $41(56.2 \%)$ & 73 & 0.011 \\
\hline & $\geqq 12$ & 0 & $9(100 \%)$ & 9 & \\
\hline \multicolumn{6}{|l|}{ Non-tumor part } \\
\hline $\begin{array}{l}\text { Quick } \\
\text { score }\end{array}$ & $<12$ & $32(39.0 \%)$ & $50(61.0 \%)$ & 82 & N/A \\
\hline & $\geqq 12$ & 0 & 0 & 0 & \\
\hline
\end{tabular}

ENO1 overexpression is defined as a Quick score of $\geqq 12$
Table 3 Clinicopathologic characteristics of canine mammary carcinoma

\begin{tabular}{|c|c|c|c|c|}
\hline & \multicolumn{2}{|c|}{ Quick score } & \multirow[t]{2}{*}{$\mathrm{N}$} & \multirow[t]{2}{*}{$\mathbf{P}$} \\
\hline & $<12$ & $\geqq 12$ & & \\
\hline \multicolumn{5}{|l|}{ Age } \\
\hline$<11$ years & 13(81.3) & $3(18.7)$ & 16 & 1.000 \\
\hline$\geqq 11$ years & 27(81.8) & $6(18.2)$ & 33 & \\
\hline \multicolumn{5}{|l|}{ Ovariohysterectomy } \\
\hline No & $31(83.8)$ & $6(16.2)$ & 37 & 0.580 \\
\hline Yes & 10(76.9) & $3(23.1)$ & 13 & \\
\hline \multicolumn{5}{|l|}{ Tumor Size } \\
\hline $\mathrm{T} 1(<3 \mathrm{~cm})$ & 15(93.8) & $1(6.2)$ & 16 & 0.298 \\
\hline $\mathrm{T} 2(3-5 \mathrm{~cm})$ & 13(72.2) & $5(27.8)$ & 18 & \\
\hline $\mathrm{T} 3(>5 \mathrm{~cm})$ & $11(84.6)$ & $2(15.4)$ & 13 & \\
\hline \multicolumn{5}{|l|}{ Grade } \\
\hline 1 & 13(92.9) & $1(7.1)$ & 14 & 0.199 \\
\hline$\|/\| \|$ & $27(77.1)$ & $8(22.9)$ & 35 & \\
\hline \multicolumn{5}{|l|}{ Histological classification } \\
\hline Carcinoma in benign tumor & $4(80.0)$ & $1(20.0)$ & 5 & 0.566 \\
\hline Complex carcinoma & 17(89.5) & $2(10.5)$ & 19 & \\
\hline Simple carcinoma & 20(76.9) & $6(23.1)$ & 26 & \\
\hline \multicolumn{5}{|l|}{ Location of affected gland } \\
\hline cranial & 13(76.5) & $4(23.5)$ & 17 & 0.566 \\
\hline caudal & 25(83.3) & $5(16.7)$ & 30 & \\
\hline \multicolumn{5}{|l|}{$E R$} \\
\hline Negative & $22(81.5)$ & $5(18.5)$ & 27 & 1.000 \\
\hline Positive & 19(82.6) & $4(17.4)$ & 23 & \\
\hline \multicolumn{5}{|l|}{$P R$} \\
\hline Negative & $2(100.0)$ & $0(0.0)$ & 2 & 1.000 \\
\hline Positive & 39(81.3) & $9(18.7)$ & 48 & \\
\hline \multicolumn{5}{|l|}{ HER2 Overexpression } \\
\hline Negative & $35(83.3)$ & $7(16.7)$ & 42 & 0.574 \\
\hline Positive & $6(75.0)$ & $2(25.0)$ & 8 & \\
\hline \multicolumn{5}{|l|}{ ER with Quick score } \\
\hline$<12$ & $38(86.4)$ & $6(13.6)$ & 44 & 0.063 \\
\hline$\geqq 12$ & $3(50.0)$ & $3(50.0)$ & 6 & \\
\hline
\end{tabular}

${ }^{1}$ Tumor size measures maximum diameter

The ENO1 overexpression may be used as a marker for poor outcome in this disease.

\section{Methods}

\section{Patient Samples}

Formalin-fixed, paraffin-embedded, surgically resected tissue of canine mammary tumor diagnosed between January 2003 and April 2008 were retrieved from the archives of the School of Veterinary Medicine, National Taiwan University, Taiwan. A cohort of eighty-two dogs including twenty-one Maltese, ten Yorkshire terriers, nine ShihTzus, seven Pomeranians, two Cocker spaniels, two French spaniels, two Bichon Frisé, one poodle, one German shepherd dog, one Shiba, one Beagle, one Labrador Retriever and twenty-four mongrels with canine mammary 


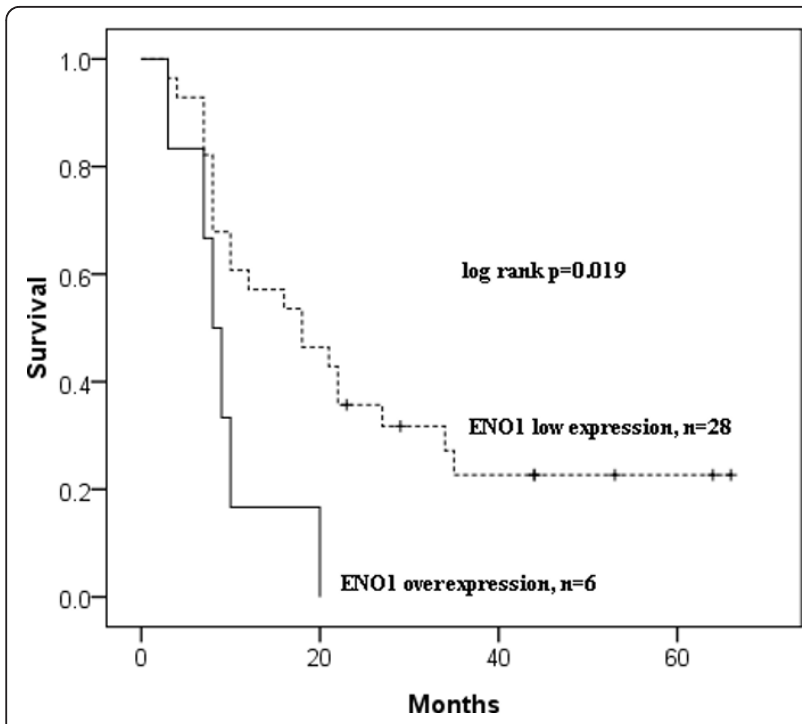

Figure 3 Kaplan-Meier curves for cause-specific survival of canine mammary carcinoma patients with and without ENO1 overexpression. Sixteen of the fifty cases lacked survival data and were excluded from the analysis.

tumor were analyzed in this study. Archived hematoxylin and eosin (HE) sections from samples fixed in $10 \%$ buffered formalin and embedded in paraffin wax were reviewed to assess the diagnoses. The tumors were diagnosed according to the World Health Organization (WHO) Histological Classification of Mammary Tumors of the Dog and the Cat [32]. Tumor size was classified according to the WHO Clinical Staging System TNM as $\mathrm{T} 1$ ( $<3 \mathrm{~cm}$ maximum diameter), T2 $(3-5 \mathrm{~cm}$ maximum diameter) and T3 (> $5 \mathrm{~cm}$ maximum diameter) [33]. The largest one was used as the basis for classification in cases of more than one tumor. Histological grading was performed on HE-stained sections and graded by a scheme based on tubule formation, nuclear pleomorphism, and mitotic counts $[34,35]$. Each feature was scored 1 to 3 points. The scores were then added to obtain the tumor grade. Final scores of 3-5 points, well-differentiated, were designated grade I; scores of 6 and 7 points, moderately differentiated carcinoma, were designated grade II; and scores of 8 and 9 points, poorly differentiated carcinoma, were designated grade III.

\section{Immunoblotting}

To detect endogenous the ENO1 protein and examine antibody specificity, canine mammary carcinoma cell

Table 4 Overexpression of ENO1 and age in the Cox regression model for predicting Cause-specific survival

\begin{tabular}{lcc}
\hline Variable & Hazard ratio $(\mathbf{9 5 \%} \mathrm{Cl})$ & $\boldsymbol{P}$ \\
\hline ENO1 overexpression & $2.71(1.03-7.15)$ & 0.044 \\
Age (11 y.o.) & $1.42(0.57-3.58)$ & 0.456 \\
\hline
\end{tabular}

line CF41 (ATCC, Rockville, MD, USA) was lysed in PBS/TDS lysis buffer $\left(10 \mathrm{mM} \mathrm{Na}{ }_{2} \mathrm{HPO}_{4} / 150 \mathrm{mM} \mathrm{NaCl} /\right.$ $1 \%$ Triton $\mathrm{X}-100 / 0.5 \%$ sodium deoxycholate/0.1\% SDS/ $10 \mathrm{mM} \mathrm{NaF}, \mathrm{pH}$ 7.25) containing the protease inhibitor cocktail (Calbiochem, San Diego, CA). The protein concentrations of the lysates were determined using the BCA protein assay kit (Pierce, Rockford, IL). The lysates were resolved in a $10 \%$ SDS-containing polyacrylamide gel, blotted on a nitrocellulose membrane, and probed with anti-ENO1 antibody (clone 8G8, Abnova Co., Taipei, Taiwan) in 1:2000 dilution, or with pre-immunized mouse total IgG. The immunocomplex was detected by the goat anti-mouse IgG antibody conjugated with horseradish peroxidase (Jackson ImmunoResearch Labs, West Grove, PA) and visualized by SuperSignal chemiluminescence (Pierce, Rockford, IL). $\beta$-Actin (Sigma, St. Louis, MO) was the loading control.

\section{Immunohistochemistry}

Paraffin-embedded canine mammary tumor tissue sections $(4-\mu \mathrm{m})$ on poly-1-lysine-coated slides were first dewaxed in xylene and re-hydrated through graded alcohols, followed by a rinse using $10 \mathrm{mM}$ Tris- $\mathrm{HCl}$ (pH 7.4) and $150 \mathrm{mM}$ sodium chloride, then treated with 3\% hydrogen peroxide for $5 \mathrm{~min}$. Slides were incubated with 1:2000 dilution of anti-ENO1 antibody for 1 hour at room temperature, then thoroughly washed three times with PBS. Bound antibodies were detected using the LSAB + kit (DAKO, Carpinteria, CA). The slides were then counterstained with Gill Hematoxylin Solution II (MERCK, Darmstadt, Germany). Paraffin-embedded sections of human breast cancer cells of homogeneous ENO1 immunophenotype were included as positive controls. Negative controls had the primary antibody omitted and replaced by pre-immunized mouse total IgG. Quantification of immunohistochemistry was carried out using Quick score which multiply the staining intensity by the percentage of positive cells [36-38]. The intensity of staining was scored as $0,1,2$, and 3 standing for negative, weak, moderate, and strong staining, respectively. The percentage of tumor cells staining positively was scored as follows: $0=0 \%, 1=1-20 \%, 2=21-40 \%, 3=41-60 \%$, $4=61-80$, and $5=81-100 \%$, compared with the total of tumor cells.

Immunohistochemistry was also performed in parallel as described above with mouse monoclonal antibodies for ER (clone 1D5, 1:35 dilution, Dako, Denmark), PR (clone SP2, 1:200 dilution, Thermo Scientific, Fremont, CA), and HER2 (A0485, 1:400 dilution, Dako, Denmark). ER and PR immunoreactivity was considered positive when more than $10 \%$ of the neoplastic cells expressed this marker [4]. The American Society of Clinical Oncology/College of American Pathologists guidelines were used to evaluate HER2 expression $(0=$ no staining 
or membrane staining in fewer than $10 \%$ of tumor cells; $1+=$ faint, barely perceptible membrane staining in more than $10 \%$ of tumor cells; $2+=$ weak to moderate complete membrane staining observed in more than $10 \%$ of tumor cells or strong complete membrane staining in less than $30 \%$ of tumor cells; $3+=$ strong and complete membrane staining in more than $30 \%$ tumor cells)[39]. In this study, overexpression of HER2 was defined as a score of $3+$.

Histological grading and immunohistochemical results were evaluated by two investigators (veterinary pathologists) scoring independently. Conflicting scores were resolved at a double-headed microscope.

\section{Statistical Analysis}

Overexpression of ENO1 was defined as a Quick score of 12 or greater on the scale of 0 to 15 . Patient data were obtained from medical records. Correlations of ENO1 and clinicopathologic parameters of canine mammary carcinoma were examined by Pearson's chi-square test. Survival rate was calculated using Kaplan-Meier analysis and compared by the Cochran-Mantel-Haenszel test (log-rank test). Cox proportional hazards regression model was used to control the effect of age on survival. Cause-specific survival was defined as the time between date of diagnosis and date of cancer-related death. Follow-up was obtained by telephone call up to August 2010. If a patient had died, the information regarding the cause of death was obtained by contact with the veterinarian. Subjects still alive at the end of the study were censored at the date of last follow-up. Cases that lacked survival data were excluded from the analysis. A $P$ value of less than 0.05 was considered to indicate statistical significance.

\section{Acknowledgements}

This study was supported by grants from the Department of Health, Taiwan (DOH100-TD-C-111-002 and DOH97-TD-G-111-022) and the National Science Council of Taiwan (NSC 100-3112-B-400-009 and NSC 98-2313-B-002-026-MY3).

\section{Author details}

'Department of Pathology, St. Martin De Porres Hospital, No. 565, Section 2, Daya Road, Chiayi, 60069, Taiwan. ${ }^{2}$ Department and Graduate Institute of Veterinary Medicine, School of Veterinary Medicine, National Taiwan University, No. 1, Section 4, Roosevelt Road, Taipei, 10617, Taiwan. ${ }^{3}$ Graduate Institute of Medicine, Kaohsiung Medical University, No. 100, Shih-Chuan 1st Road, Kaohsiung, 80708, Taiwan. ${ }^{4}$ National Institute of Cancer Research, National Health Research Institutes, No.367, Shengli Road, Tainan, 70456, Taiwan. ${ }^{5}$ Cancer Center, Kaohsiung Medical University Hospital, No. 100, Tzyou 1st Road, Kaohsiung, 80708, Taiwan.

\section{Authors' contributions}

PYC drafted the manuscript, NCH performed the statistical analysis, ATL carried out the immunohistochemical staining, NYS, MFH, and CHL designed the study. All authors read and approved the final manuscript.

Received: 10 May 2011 Accepted: 21 October 2011

Published: 21 October 2011
References

1. Cotchin E: Mammary neoplasms of the bitch. J Comp Pathol 1958, 68(1):1-22

2. Moulton JE, Taylor DO, Dorn CR, Andersen AC: Canine mammary tumors. Pathol Vet 1970, 7(4):289-320.

3. Prier JE, Brodey RS: Canine Neoplasia. A Prototype for Human Cancer Study. Bull World Health Organ 1963, 29:331-344.

4. Gama A, Alves A, Schmitt F: Identification of molecular phenotypes in canine mammary carcinomas with clinical implications: application of the human classification. Virchows Arch 2008, 453(2):123-132.

5. Ferreira E, Gobbi H, Saraiva BS, Cassali GD: Columnar cell lesions of the canine mammary gland: pathological features and immunophenotypic analysis. BMC Cancer 2010, 10:61

6. Mouser P, Miller MA, Antuofermo E, Badve SS, Mohammed SI: Prevalence and classification of spontaneous mammary intraepithelial lesions in dogs without clinical mammary disease. Vet Pathol 2010, 47(2):275-284.

7. Vinothini G, Balachandran C, Nagini S: Evaluation of molecular markers in canine mammary tumors: correlation with histological grading. Oncol Res 2009, 18(5-6):193-201.

8. Strandberg JD, Goodman DG: Animal model of human disease: canine mammary neoplasia. Am J Pathol 1974, 75(1):225-228.

9. Martin PM, Cotard M, Mialot JP, Andre F, Raynaud JP: Animal models for hormone-dependent human breast cancer. Relationship between steroid receptor profiles in canine and feline mammary tumors and survival rate. Cancer Chemother Pharmacol 1984, 12(1):13-17.

10. Pancholi V: Multifunctional alpha-enolase: its role in diseases. Cell Mol Life Sci 2001, 58(7):902-920.

11. Jiang BH, Agani F, Passaniti A, Semenza GL: V-SRC induces expression of hypoxia-inducible factor 1 (HIF-1) and transcription of genes encoding vascular endothelial growth factor and enolase 1: involvement of HIF-1 in tumor progression. Cancer Res 1997, 57(23):5328-5335.

12. Wygrecka M, Marsh LM, Morty RE, Henneke I, Guenther A, Lohmeyer J, Markart P, Preissner KT: Enolase-1 promotes plasminogen-mediated recruitment of monocytes to the acutely inflamed lung. Blood 2009, 113(22):5588-5598

13. Arza B, Felez J, Lopez-Alemany R, Miles LA, Munoz-Canoves P: Identification of an epitope of alpha-enolase (a candidate plasminogen receptor) by phage display. Thromb Haemost 1997, 78(3):1097-1103.

14. Redlitz A, Fowler BJ, Plow EF, Miles LA: The role of an enolase-related molecule in plasminogen binding to cells. Eur J Biochem 1995, 227(1-2):407-415.

15. Nakajima K, Hamanoue M, Takemoto N, Hattori T, Kato K, Kohsaka S: Plasminogen binds specifically to alpha-enolase on rat neuronal plasma membrane. J Neurochem 1994, 63(6):2048-2057.

16. Miles LA, Dahlberg CM, Plescia J, Felez J, Kato K, Plow EF: Role of cellsurface lysines in plasminogen binding to cells: identification of alphaenolase as a candidate plasminogen receptor. Biochemistry 1991, 30(6):1682-1691.

17. Dudani AK, Cummings C, Hashemi S, Ganz PR: Isolation of a novel $45 \mathrm{kDa}$ plasminogen receptor from human endothelial cells. Thromb Res 1993, 69(2):185-196.

18. Altenberg B, Greulich KO: Genes of glycolysis are ubiquitously overexpressed in 24 cancer classes. Genomics 2004, 84(6):1014-1020.

19. Chang GC, Liu KJ, Hsieh CL, Hu TS, Charoenfuprasert S, Liu HK, Luh KT Hsu LH, Wu CW, Ting CC, et al: Identification of alpha-enolase as an autoantigen in lung cancer: its overexpression is associated with clinical outcomes. Clin Cancer Res 2006, 12(19):5746-5754.

20. Hennipman A, van Oirschot BA, Smits J, Rijksen G, Staal GE: Glycolytic enzyme activities in breast cancer metastases. Tumour Biol 1988, 9(5):241-248.

21. Peebles KA, Duncan MW, Ruch RJ, Malkinson AM: Proteomic analysis of a neoplastic mouse lung epithelial cell line whose tumorigenicity has been abrogated by transfection with the gap junction structural gene for connexin 43, Gja1. Carcinogenesis 2003, 24(4):651-657.

22. Tsai ST, Chien IH, Shen WH, Kuo YZ, Jin YT, Wong TY, Hsiao JR, Wang HP, Shih NY, Wu LW: ENO1, a potential prognostic head and neck cancer marker, promotes transformation partly via chemokine CCL20 induction. Eur J Cancer 2010, 46(9):1712-1723.

23. Wu W, Tang X, Hu W, Lotan R, Hong WK, Mao L: Identification and validation of metastasis-associated proteins in head and neck cancer cell lines by two-dimensional electrophoresis and mass spectrometry. Clin Exp Metastasis 2002, 19(4):319-326. 
24. Zhang L, Cilley RE, Chinoy MR: Suppression subtractive hybridization to identify gene expressions in variant and classic small cell lung cancer cell lines. J Surg Res 2000, 93(1):108-119.

25. Takashima M, Kuramitsu Y, Yokoyama Y, lizuka N, Fujimoto M, Nishisaka T, Okita K, Oka M, Nakamura K: Overexpression of alpha enolase in hepatitis $C$ virus-related hepatocellular carcinoma: association with tumor progression as determined by proteomic analysis. Proteomics 2005, 5(6):1686-1692.

26. Takikita M, Altekruse S, Lynch CF, Goodman MT, Hernandez BY, Green M, Cozen W, Cockburn M, Sibug Saber M, Topor M, et al: Associations between selected biomarkers and prognosis in a population-based pancreatic cancer tissue microarray. Cancer Res 2009, 69(7):2950-2955.

27. Tu SH, Chang CC, Chen CS, Tam KW, Wang YJ, Lee CH, Lin HW, Cheng TC, Huang CS, Chu JS, et al: Increased expression of enolase alpha in human breast cancer confers tamoxifen resistance in human breast cancer cells. Breast Cancer Res Treat 2010, 121(3):539-553.

28. Hamaguchi $T$, lizuka N, Tsunedomi R, Hamamoto $Y$, Miyamoto $T$, lida $M$, Tokuhisa Y, Sakamoto K, Takashima M, Tamesa T, et al: Glycolysis module activated by hypoxia-inducible factor 1alpha is related to the aggressive phenotype of hepatocellular carcinoma. Int J Oncol 2008, 33(4):725-731.

29. Racz A, Brass N, Hofer M, Sybrecht GW, Remberger K, Meese EU: Gene amplification at chromosome 1pter-p33 including the genes PAX7 and ENO1 in squamous cell lung carcinoma. Int J Oncol 2000, 17(1):67-73.

30. He P, Naka T, Serada S, Fujimoto M, Tanaka T, Hashimoto S, Shima Y, Yamadori T, Suzuki H, Hirashima T, et al: Proteomics-based identification of alpha-enolase as a tumor antigen in non-small lung cancer. Cancer $\mathrm{SCl}$ 2007, 98(8):1234-1240

31. Tiseo M, Ardizzoni A, Cafferata MA, Loprevite M, Chiaramondia M, Filiberti R, Marroni P, Grossi F, Paganuzzi M: Predictive and prognostic significance of neuron-specific enolase (NSE) in non-small cell lung cancer. Anticancer Res 2008, 28(1B):507-513.

32. Misdorp W, Else RW, Hellmén E, Lipscomb TP: Histological Classification of Mammary Tumors of the Dog and Cat. Washington, D. C.: American Registry of Pathology; 1999.

33. Owen LN: The TNM Classification of Tumors in Domestic Animals. Geneva: World Health Organization; First 1980.

34. Elston CW, Ellis IO: Pathological prognostic factors in breast cancer. I. The value of histological grade in breast cancer: experience from a large study with long-term follow-up. Histopathology 1991, 19(5):403-410.

35. Karayannopoulou M, Kaldrymidou E, Constantinidis TC, Dessiris A: Histological grading and prognosis in dogs with mammary carcinomas: application of a human grading method. $J$ Comp Pathol 2005, 133(4):246-252.

36. Charafe-Jauffret E, Tarpin C, Bardou VJ, Bertucci F, Ginestier C, Braud AC, Puig B, Geneix J, Hassoun J, Birnbaum D, et al: Immunophenotypic analysis of inflammatory breast cancers: identification of an 'inflammatory signature'. J Pathol 2004, 202(3):265-273.

37. Briffod M, Hacene K, Le Doussal V: Immunohistochemistry on cell blocks from fine-needle cytopunctures of primary breast carcinomas and lymph node metastases. Mod Pathol 2000, 13(8):841-850.

38. Li J, Martinka M, Li G: Role of ING4 in human melanoma cell migration, invasion and patient survival. Carcinogenesis 2008, 29(7):1373-1379.

39. Wolff AC, Hammond ME, Schwartz JN, Hagerty KL, Allred DC, Cote RJ, Dowsett M, Fitzgibbons PL, Hanna WM, Langer A, et al: American Society of Clinical Oncology/College of American Pathologists guideline recommendations for human epidermal growth factor receptor 2 testing in breast cancer. J Clin Oncol 2007, 25(1):118-145.

doi:10.1186/1746-6148-7-62

Cite this article as: Chu et al:: Overexpression of $\alpha$-enolase correlates with poor survival in canine mammary carcinoma. BMC Veterinary Research 2011 7:62.

\section{Submit your next manuscript to BioMed Central and take full advantage of:}

- Convenient online submission

- Thorough peer review

- No space constraints or color figure charges

- Immediate publication on acceptance

- Inclusion in PubMed, CAS, Scopus and Google Scholar

- Research which is freely available for redistribution

Submit your manuscript at www.biomedcentral.com/submit
Biomed Central 